\title{
PENGARUH CARA PEMASAKAN BERBEDA TERHADAP KELARUTAN PROTEIN DAN PERUBAHAN KANDUNGAN KIMIA IKAN SEMBILANG (Paraplotosus albilabris)
}

\section{THE EFFECT OF DIFFERENT COOCKING METHODS ON PROTEIN SOLUBILITY AND CHANGES IN THE CHEMICAL CONTENT OF THE CAT FISH (Paraplotosus albilabris)}

\author{
Siti Rokayah $^{1}$, Edison ${ }^{1}$, Sumarto ${ }^{1}$ \\ ${ }^{1}$ Teknologi Hasil Perikanan Fakultas Perikanan dan Kelautan Universitas Riau, Jl. HR Soebrantas Km \\ 12,5 Simpang Baru, Panam - Pekanbaru, Indonesia 28293 \\ Correspondence Author : sumarto1976@yahoo.co.id
}

A R T I C L E I N F O

Submitted: 02 Mei 2018

Revised : 26 Juni 2018

Approved: 10 Juni 2018

\begin{abstract}
This study aimed to know the value of rendement, chemical content of fresh sembilang fish meat and after experiencing coocking, and water soluble protein and salt soluble protein. The method used in this research was experimental method with Completely Randomized Design (CRD) which consists of 4 levels of treatment, with $R_{0}$ (without coocking), $R_{1}$ (boiling), $R_{2}$ (boiling with salt), $R_{3}$ (steaming).. The results showed that the average yield value is $47.7 \% \%$, in the proximate analysis of fresh sembilang fish meat contains moisture 59.25\%, ash $1.42 \%$, fat $6.01 \%$, and protein content $28.39 \%$. The nutrient content of the fish after the cooking differs based on the analysis performed on each treatment R1, R2, R3 has no significant effect on water content, ash content, and protein content, but has significant effect on fat content.

Analysis of water soluble protein had a value $4.16 \%, 3.97 \%$, $3.85 \%$ and $3.18 . \%$
\end{abstract}

\section{Abstrak}

Penelitian ini bertujuan untuk mengetahui nilai rendemen, kandungan kimia pada daging ikan sembilang segar, serta protein larut air dan protein larut garam (PLA dan PLG). Metode yang digunakan adalah metode eksperimen, dengan Rancangan Acak Lengkap (RAL) yang terdiri dari 4 taraf perlakuan yaitu tanpa proses pemasakan/segar $\left(\mathrm{R}_{0}\right)$, perebusan tanpa garam $\left(R_{1}\right)$, perebusan dengan garam $3 \% \quad\left(R_{2}\right)$, pengukusan $\left(\mathrm{R}_{3}\right)$.. Hasil penelitian menunjukkan rata-rata nilai rendemen $47.7 \%$, analisis proksimat daging segar kadar air $59.25 \%$, abu $1.42 \%$, lemak $6.01 \%$, dan protein $28.39 \%$. Kandungan gizi ikan sembilang setelah mengalami pemasakan berbeda berdasarkan analisis yang dilakukan pada setiap perlakuan $\mathrm{R}_{1}, \mathrm{R}_{2}, \mathrm{R}_{3}$ tidak berpengaruh nyata terhadap kadar air, kadar abu, dan kadar protein, namun berpengaruh nyata terhadap kadar lemak. Analisis protein larut air memiliki nilai $4.26 \%, 3.72 \%, 3.26 \%$, dan $3.38 \%$, analisis protein larut garam memiliki nilai $4.16 \%, 3.97 \%, 3.85 \%$, dan 3 . 


\section{PENDAHULUAN}

Ikan sembilang merupakan hasil laut yang Indonesia merupakan negara kepulauan terbesar di dunia yang memiliki 17.504 pulau dan garis pantai lebih dari $81.000 \mathrm{~km}$ dengan luas perairan laut sekitar 5,8 juta $\mathrm{km}^{2} \quad(75 \%$ dari total Wilayah Indonesia). Kondisi alam dan iklim yang tidak fluktuatif, menjadikan Indonesia mempunyai potensi sumber daya laut dengan keanekaragaman hayati yang sangat besar, walaupun belum termanfaatkan secara maksimal (Reina, 2004). Mengingat prospek ekonomi yang besar dari sumber-sumber hayati di laut sebagai bahan obat-obatan, Departemen Kelautan dan Perikanan (DKP) menjadikan bioteknologi kelautan sebagai program unggulan sejak tahun 2002 (Dahuri, 2005).

Ikan merupakan bahan makanan yang popular bagi masyarakat Indonesia. Selain merupakan komoditas yang mudah dijumpai, ikan memiliki kelebihan nutrisi dibanding dengan produk hewani lain dimana ikan mengandung protein hingga $20 \%$, asam lemak tak jenuh dan kolesterol yang sangat rendah sehingga aman dikonsumsi secara rutin (Afrianto dan Liviawaty, 1989).

Menurut Fellow dalam Dwiari, (2008), Proses pemasakan biasanya melibatkan pengolahan dengan suhu tinggi (proses termal) seperti digoreng, dibakar, direbus dan dikukus merupakan salah satu metode terpenting yang digunakan dalam pengolahan makanan karena memiliki efek yang diinginkan pada kualitas makanan (matang, pembentukan flavor tertentu), memiliki efek pengawetan, memperbaiki ketersediaan beberapa zat gizi dan kontrol kondisi pengolahan yang relatif sederhana. Menurut Fellow (2000), Pengukusan (pemanasan basah) merupakan metode yang sering digunakan. Pengukusan atau penggunaan uap sebagai sumber panas memiliki keuntungan yaitu hilangnya vitamin dan komponen makanan lain yang sensitif terhadap panas lebih kecil.

Penelitian ini bertujuan untuk mengetahui kandungan kimia daging ikan sembilang pada daging segar dan setelah dilakukan pemasakan berbeda, mengetahui nilai rendemen, dan mengetahui protein larut air dan protein larut garam.

\section{METODE PENELITIAN. \\ Bahan dan alat}

Bahan-bahan yang digunakan adalah ikan sembilang (Paraplotosus albilabris) hasil tangkapan (berasal dari perairan Bagansiapiapi, Provinsi Riau) sebanyak 16 ekor dengan ukuran 30-35 $\mathrm{cm}$ dan berat $400-450 \mathrm{~kg}$, es untuk proses pendinginan, aquades, garam, $\mathrm{H}_{2} \mathrm{SO}_{4}, \mathrm{HCL}$, asam borax, katalis, indicator campuran, $\mathrm{NaOH}$, indokator Fenolftelain/ Phenolphthalein (PP), $\mathrm{Na}_{2} \mathrm{SO}_{4}$ dan $\mathrm{H}_{3} \mathrm{BO}_{3}$.

Alat yang digunakan dalam penelitian ini antara lain oven, tanur, desikator, tabung reaksi, Erlenmeyer, tabung Sokhlet, tabung Kjeldahl, destilator, buret, pipet tetes, gelas ukur, cawan abu porselen, labu destilasi, styrofoam, selongsong lemak, pemanas listrik, sentrifuse, buret, thermometer.

Metode yang digunakan dalam penelitian ini adalah metode eksperimen (Purwaningsih et al.,2014) yaitu dengan melakukan serangkaian Dengan rancangan percobaan yang digunakan adalah rancangan acak lengkap (RAL) non faktorial yang terdiri dari 4 taraf perlakuan yaitu $R_{0}$ (tanpa proses pemasakan/ segar), $\mathrm{R}_{1}$ (perebusan tanpa garam), $R_{2}$ (perebusan dengan garam 3 $\%), R_{3}$ (pengukusan).

Masing-masing taraf dilakukan pengulangan sebanyak 3 kali, dan jumlah satuan percobaan pada penelitian ini adalah 12 unit percobaan dan 2 parameter percobaan yaitu uji kelarutan protein (PLA dan PLG) dan analisis proksimat (kadar air, kadar lemak, kadar protein, dan kadar abu). Masing-masing taraf 
percobaan menggunakan suhu $70-80^{\circ} \mathrm{C}$ dengan lama waktu 10 menit.

Preparasi bahan baku daging dan analisis proksimat tahap 1

Pada tahap sampel ikan sembilang (Paraplotosus albilabris) yang masih dalam keadaan segar dijadikan sebagai control dan sampel untuk proses pemasakan dilakukan penanganan penyiangan, pembuangan insang, jeroan dan patil. Ikan dibuang insang serta isi perutnya. Kemudian ikan sembilang dicuci bersih menggunakan air. Kemudian setelah didapat daging dilanjutkan analisis proksimat (AOAC, 2005) pada daging segar yang meliputi kadar air, kadar abu, kadar lemak, dan kadar protein.

Analisis Proksimat dan PLA, PLG tahap 2

Setelah tahapan preparasi selesai, sampel dipilah antara yang akan dijadikan kontrol dan yang akan dilakukan pemasakan. Ikan sembilang yang dijadikan sebagai control dipisahkan antara daging dan tulangnya, sedangkan ikan sembilang yang akan dilakukan proses pemasakan dipilah lagi untuk diberikan perlakuan perebusan, perebusan dengan garam dan pengukusan dengan suhu yaitu $70-80^{\circ}$ dan lama waktu 10 menit (Zhou et al. 2011 dengan modifikasi).

\section{Analisis Data}

Data yang diperoleh dari hasil penelitian sesuai dengan parameter uji kemudian ditabulasikan ke dalam bentuk tabel dan dianalisis secara statistik kemudian dilanjutkan dengan analisis variansi (ANAVA). Berdasarkan analisis variansi, jika $F_{\text {hitung }}>F_{\text {tabel }}$ pada tingkat kepercayaan $95 \%$ berarti hipotesis ditolak, kemudian dilanjutkan dengan uji lanjut. Apabila $\quad F_{\text {hitung }}<\mathrm{F}_{\text {tabel }}$ maka hipotesis diterima dan tidak dilakukan uji lanjut.
HASIL DAN PEMBAHASAN Karakteristik fisik teripang pasir (Holothuria scabra)

Bentuk tubuh ikan sembilang hampir sama dengan lele, namun berukuran agak besar dengan memiliki 4 sungut dan memiliki sepasang patil dibagian bawah. Patil pada catfish merupakan modifikasi sirip pektoral yang berupa duri tajam. Patil yang dimiliki catfish umumnya adalah patil yang keras, tajam, dan terdapat kelenjar racun (Satora et al., 2008).

\section{Rendemen ikan sembilang}

Rendemen merupakan suatu parameter yang paling penting untuk mengetahui nilai ekonomis dan efektifitas suatu produk atau bahan. Rendemen ikan sembilang merupakan bagian tubuhnya yang masih bisa dipergunakan yang diperoleh dengan cara memisahkan bagian isi antara bagian daging, kulit, jeroan, dan kotorannya. Semakin besar nilai rendemen, maka semakin besar pula bagian bahan baku yang dapat dimanfaatkan (Hayati, 2012).

Berdasarkan data yang didapatkan bahwan rata-rata rendemen daging ikan sembilang yang dihasilkan adalah $47.7 \%$ pada setiap perlakauan cara pemasakan berbeda. Daging ikan sembilang setelah proses cara pemasakan berbeda mengalami perubahan jumlah berat, penyusutan pada saat perebusan menyebabkan kandungan air bebas yang terdapat pada daging keluar sehingga terjadi pengurangan berat.

\section{Komposisi kimia ikan sembilang}

Kandungan kimia dari daging ikan sembilang yang meliputi kadar air, kadar abu, kadar lemak, dan kadar protein disajikan (Tabel 1). 
Tabel 1. Uji proksimat daging ikan sembilang segar dan setelah perlakuan cara pemasakan berbeda

\begin{tabular}{lrrrr}
\hline \multirow{2}{*}{ Kandungan } & \multicolumn{4}{c}{ Perlakuan (\%) } \\
\cline { 2 - 5 } & \multicolumn{1}{c}{$\mathrm{R}_{0}$} & \multicolumn{1}{c}{$\mathrm{R}_{1}$} & \multicolumn{1}{c}{$\mathrm{R}_{2}$} & \multicolumn{1}{c}{$\mathrm{R}_{3}$} \\
\hline \multirow{2}{*}{ Air } & 59.25 & 57.32 & 58.57 & 56.94 \\
Abu & 1.42 & 1.09 & 1.34 & 1.25 \\
Lemak & 6.01 & 4.73 & 5.64 & 4.33 \\
Protein & 28.39 & 25.23 & 26.30 & 25.91 \\
\hline Ket: $\mathrm{R}_{0}$ : Segar $\mathrm{R}_{1}$ :rebus tanpa & garam & $\mathrm{R}_{2}$ :rebus \\
dengan garam $\mathrm{R}_{3}:$ kukus & & &
\end{tabular}

\section{Kadar air}

Kadar air pada Tabel 1 menunjukkan kadar air 56.94-59.25\%. rata-rata air tertinggi dimiliki oleh daging segar tanpa adanya perlakuan $\mathrm{R}_{0}$ (59.25\%), sedangkan kadar air terendah yaitu pada perlakuan $\mathrm{R}_{3}(56.94 \%)$. Hasil penelitian lain menunjukkan bahwa ratarata kadar air ikan sebesar $75.68 \%$ pada Clarias gariepinus (Firmansyah, 2015).

Perbedaan kadar air ini disebabkan oleh perbedaan penanganan dimana dalam penelitian ikan sembilang mengalami proses perebusan, perebusan dengan garam dan pengukusan, sehingga kadar air semakin menurut meskipun tidak secara signifikan, pada saat proses pemasakan cairan dalam tubuh ikan ikut keluar. Hal ini sesuai dengan yang dikemukakan Harris dan Karmas (1989) bahwa penurunan kadar air dipengaruhi oleh oleh factor pemasakan yaitu perebusan. Daging ikan yang direbus memiliki penurunan yang rendah, hal ini disebabkan oleh media air yang digunakan dalam perebusan memberikan tekanan pada bahan sehingga air dalam bahan mengalami penurunan kadar air. Hal ini sesuai dengan penelitian Purwaningsih (2014) yang menyatakan bahwa pengolahan dengan panas menurunkan kadar air ikan glodok.

\section{Kadar abu}

Rata-rata kadar abu 1.09-1.42\%. Rata-rata kadar abu tertinggi dimiliki oleh $\mathrm{R}_{0}(1.42 \%)$, sedangkan kadar abu terendah yaitu pada $\mathrm{R}_{1}(1.09 \%)$.

Kadar abu suatu bahan pangan menunjukkan besarnya jumlah mineral yang terkandung dalam bahan tersebut. Mineral yang ditemukan dalam tubuh makhluk hidup dan dalam bahan pangan tergabung dalam persenyawaan anorganik dan adapula yang ditemukan dalam bentuk unsur. Mineral bermanfaat untuk mengatur fungsi metabolisme dan psikologis yang normal di dalam tubuh organisme (Villanueva dan Bustamante, 2006). Hasil analisis ragam pada tingkat kepercayaan 95\% menunjukkan bahwa metode pengolahan memberikan pengaruh terhadap kadar abu ikan sembilang. Kadar abu mengalami penurunan setelah perebusan $(1.09 \%)$ dan pengukusan (1.25), namun mengalami kenaikan setelah perebusan dengan garam $(1.34 \%)$. Penambahan garam dalam proses pengolahan dapat meningkatkan kadar abu dalam produk. Hal ini seperti yang dikemukakan oleh Desniar et al., (2009) bahwa semakin tinggi konsentrasi garam yang digunakan pada pembuatan pedda ikan kembung (Rastrelliger kanagurta), maka kadar abunya semakin meningkat.

\section{Kadar lemak}

Rata-rata kadar lemak 4.33-6.01\%. Rata-rata kadar lemak tertinggi dimiliki oleh $\mathrm{R}_{0}(6.01 \%)$, sedangkan kadar lemak terendah yaitu pada $\mathrm{R}_{3} \quad(4.33 \%)$. Penurunan yang terjadi dipengaruhi oleh suhu pengolahan. Menurut Indarti (2007), suhu pemanasan akan menyebabkan lemak menjadi cair dan viskositas lemak akan berkurang sehingga lemak mudah keluar dari matriks sel.

Pada umumnya setelah proses pengolahan bahan pangan akan terjadi kerusakan lemak Tingkat kerusakannya sangat bervariasi tergantung pada suhu yang digunakan dan lamanya waktu proses pengolahan. Makin tinggi suhu yang digunakan, maka semakin intens kerusakan lemak (Dian, 2015).

\section{Kadar Protein}

Rata-rata kadar protein 25.23$28.39 \%$, rata-rata kadar protein tertinggi dimiliki oleh $\mathrm{R}_{0}(28.39 \%)$, sedangkan kadar protein terendah yaitu pada $R_{1}$ 
(25.23\%). Hasil analisis kadar protein pada daging ikan sembilang segar adalah $28.39 \%$, pada daging segar kadar protein pada ikan biasanya memang tinggi. Sedangkan pada perlakuan $\mathrm{R}_{1}, \mathrm{R}_{2}$ dan $\mathrm{R}_{3}$ nilai protein menurun atau mengalami penyusutan. Menurut Selcuk et al. (2010) kadar protein ikan baik dalam basis basah maupun basis kering dapat berubah tergantung kepada jenis spesies dan metode pengolahannya. Semakin tinggi suhu, protein akan terhidrolisa dan terdenaturasi, terjadi peningkatan kandungan senyawa terekstrak bernitrogen, amonia dan hidrogen sulfida dalam daging (Zaitsev et al., 1969, diacu dalam Sumiati 2008).

Perbedaan kadar protein pada daging ikan sembilang dapat dikarenakan oleh faktor spesies, umur, makanan yang tersedia, laju metabolisme, tingkat kematangan gonad, dan laju pergerakan tiap organisme. Setelah mengalami proses perebusan, perebusan dengan gram dan pengukusan kadar protein mengalami penurunan dikarenakan perebusan mengakibatkan keluarnya air bebas dari jaringan daging teripang dan terjadinya koagulasi sehingga tekstur daging memadat dan protein mengalami denaturasi sehingga membentuk struktur yang lebih sederhana dan jumlahnya dalam bahan pangan menurun. (Priebe, 2007).

\section{Analisis Protein Larut Air dan Protein Larut Garam}

Protein merupakan komponen terbesar dalam jumlahnya setelah air dan merupakan bagian yang terpenting untuk manusia. Protein daging bersifat tidak stabil dan mempunyai sifat dapat berubah (denaturasi) dengan berubahnya kondisi lingkungan (Georgiev et al., 2008). Hasil analisis protein larut air dan protein larut garam sapat dilihat pada Tabel 2.
Tabel 2. Uji kadar protein larut air dan protein larut garam

\begin{tabular}{lll}
\hline \multirow{2}{*}{ Perlakuan } & \multicolumn{2}{c}{ Rata-rata (\%) } \\
\cline { 2 - 3 } & PLA & PLG \\
\hline $\mathrm{R}_{0}$ & 4.26 & 4.16 \\
$\mathrm{R}_{1}$ & 3.72 & 3.97 \\
$\mathrm{R}_{2}$ & 3.26 & 3.85 \\
$\mathrm{R}_{3}$ & 3.38 & 3.18 \\
\hline
\end{tabular}

Rata-rata kadar protein larut air 3.26-4.26\%. Rata-rata kadar protein larut air tertinggi dimiliki oleh $\mathrm{R}_{0}(4.26 \%)$, sedangkan kadar protein larut air terendah yaitu $R_{2}(3.27 \%)$.

Rata-rata kadar protein larut garam $3.18-4.16 \%$. Rata-rata kadar protein larut garam tertinggi dimiliki oleh $\mathrm{R}_{0}(4.16 \%)$, sedangkan kadar protein larut garam terendah yaitu pada perlakuan $\mathrm{R}_{3}(3.18 \%)$. Penurunan kelarutan protein disebabkan oleh terjadinya koagulasi dan denaturasi protein. Pada saat perebusan, PLA terlepas dari daging karena larut dengan air sehingga kandungannya dalam daging teripang menurun. Kelarutan protein tergantung dari suhu, semakin tinggi suhu maka semakin banyak pula protein yang terdenaturasi (Sikorski et al.,1981).

\section{KESIMPULAN}

Ikan sembilang setelah perlakuan cara pemasakan berbeda (perebusan, perebusan dengan garam dan pengukusan) memiliki rata-rata nilai rendemen $47.7 \%$ pada daging. Kandungan gizi (proksimat) pada daging ikan sembilang segar kadar air $(59.25 \%)$, kadar abu (1.42\%), kadar lemak (6.01\%), kadar protein (28.39\%). Kandungan gizi daging ikan sembilang setelah perlakuan cara pemasakan berbeda berdasarkan analisis yang dilakukan pada setiap perlakuan $\mathrm{R}_{1}, \mathrm{R}_{2}, \mathrm{R}_{3}$ tidak berpengaruh nyata terhadap kadar air, kadar abu, dan kadar protein, namun berpengaruh nyata terhadap kadar lemak

Berdasarkan analisis yang dilakukan, kadar protein larut air pada daging ikan sembilang setelah perlakuan cara pemasakan berbeda didapatkan ratarata $\mathrm{R}_{0}(4.24 \%), \mathrm{R}_{1}(3.72 \%), \mathrm{R}_{2}(3.26 \%)$, $\mathrm{R}_{3} 3.38 \%$ dan kadar protein larut garam didapatkan rata-rata $\mathrm{R}_{0} \quad(4.16 \%), \quad \mathrm{R}_{1}$ 
$(3.97 \%), \quad \mathrm{R}_{2} \quad(3.85 \%), \quad \mathrm{R}_{3} \quad(3.18 \%)$ memberikan pengaruh nyata.

\section{SARAN}

Penulis Penulis menyarankan perlu adanya penelitian lebih lanjut mengenai lama waktu perebusan yang digunakan, metode pengolahan yang lain seperti digoreng, dipanggang untuk mengetahui dan nilai susut gizi yang terjadi pada daging ikan sembilang.

\section{UCAPAN TERIMA KASIH}

Penulis menyampaikan terima kasih kepada Bapak Drs. Edison, M.Si dan Bapak Sumarto, S.Pi, M.Si yang telah membimbing dan membantu dalam penelitian ini. Terima kasih juga kepada semua pihak yang telah membantu dalam penelitian ini.

\section{DAFTAR ACUAN}

Abun. 2006. Protein dan Asam Amino. Bandung: UNPAD Press.

Adawiyah, R. 2007. Pengolahan dan Pengawetan Ikan. Jakarta: Bumi Aksara.

Ahmadi, T. E. 2009. Teknologi Pengolahan Pangan. Jakarta: PT Bumi Aksara.

Alpatih, A., Mifbakhuddin, M., dan Nurullita.2010. Pengaruh Konsentrasi Larutan Asam Jeruk Nipis dan Lama Perendaman Terhadap Penurunan Kadar Logam Berat Timbal $(\mathrm{Pb})$ dalam Daging Kerang Hijau (Perna viridis) .Skripsi. Fakultas Kesehatan Masyarakat. Universitas Muhammadiyah Semarang. Semarang.

Apriyantono A, dkk. 1989. Petunjuk Laboratorium Analisis Pangan. Bogor: PAU. Institut Pertanian Bogor.
Ball, D. V. And K. V. Rao. 1984. Marine Fisheries. Mc. Graw Hill Publishing Company Limited, New Delhi. India. 472 hal.

Choudhary A, Pandey P. 2013. Effect of Catfish Venom on HaematologicalParameters in Albino Rat. Indian Journal of Fundamental and AppliedLife Sciences Vol. 3(1): 9-15

DeMan, J.M. 1997. Kimia Makanan. Palmamirata K, penerjemah. Bandung: Penerbit ITB.[DKP] Departemen Kelautan dan Perikanan. 2007. Sistem Informasi Data

Statistik.www.simpatik.com.[27 Maret 2017].

Dian, S., Almasyhuri ., dan Astuti, L. 2015. Pengaruh Proses Pemasakan Terhadap Komposisi Zat Gizi Bahan Pangan Sumber Protein. Pusat Biomedis dan teknologi Dasar Kesehatan. Jakarta

Dwiari, S.R., Asadayanti D.D., Nurhayati, Sofyaningsih M., Yudhanti S.F.A.R., Yoga I.B.K.W. 2008. Teknologi Pangan untuk Sekolah Menengah Kejuruan Jilid 1. Direktorat Pembinaan Sekolah Menengah Kejuruan Direktorat Jenderal Manajemen Pendidikan Dasar dan Menengah Departemen Pendidikan Nasional. Jakarta.

Efrison. 2004. Pengaruh Pengukusan Terhadap Kadar Kolesterol pada berbagai Organ Ayam Boiler. [Skripsi]. Tidak Dipublikasikan. Yogyakarta

Erkan N, Ozden O. 2011. A prelimimary study of amino acid and mineral profiles of important and estimable 21 seafood species. British Food Journal 4(113): 457-569 
Erlangga. 2009. Kemunduran mutu fillet ikan Lele Dumbo (Clarias gariepinusI) pada penyimpanan suhu Chilling dengan perlakuan cara kematian. [Skripsi]. Institut Pertanian Bogor

Fathul, F. 2007. PenentuanKualitas danKuantitas Kandungan Zat Makanan. Penuntun Praktikum. Lampung:Universitas Lampung. 39 hlm.

Fellows, P. 2000. Food Processing Technologyi: Principles and Practice.Woodhead Publ. Ltd. Cambridge.

Firmansyah. 2015. Pengaruh Jumlah Surimi Ikan Lele Dumbo (Clarias gariepinus) Terhadap Mutu Nugget. Universitas Riau. Pekanbaru

Georgiev, L. Penchev G, Dimitrov D and Palov A. 2008. Structural change in common (Cyprinus carpio L) fish meat during freezing. Bulgaria Journal Of Veterinary Medicine. 2(2): 13 1-136

Gunawan. 2010. Asam Amino. www.scribd.com. Diakses 27 Maret 2017

Haetami, RR. 2008. Karakteristik Surimi Hasil Pengkomposisian Tetelan Ikan kakap merah (Lutjanus $s p$ ) dan ikan layang (Decapterus $s p$ ) pada Penyimpanan Beku. [Skripsi]. Bogor: Fakultas Perikanan dan Ilmu Kelautan, Institut Pertanian Bogor

Hamyani, E. Utami. T. dan Khairina. R. 2000. Pemanfaatan Asap Cair Pada Pengolahan "wadi" Ikan Betok (Anabas testudineus Bloch) Makanan Hasil Fermentasi. Jurnal
Makanan Tradisional Indonesia Vol. 2 No.3: 1-10

Harris, R.S, Karnas E. 1989. Evaluasi Gizi Pada Pengolahan Bahan Pangan. Achmadi S, penerjemah. Bandung: Penerbit ITB.

Hayati A, 2012. Pengaruh Perendaman Asam Organik Terhadap Kelarutan Mineral Kerang Darah (Anadara granosa). Skripsi. Fakultas Perikanan dan Ilmu Kelautan, Institut Pertanian Bogor.

Kottelat, M. 1993. Ikan Air Tawar Indonesia Bagian Barat dan Sulawesi Edisi Dwi Bahasa Inggris-Indonesia. Jakarta (ID): Java Books. hlm 293

Kuncoro, Budi Eko. dan Wiharto, F. E. Ardi. 2009. Ensiklopedia Populer Ikan Air Laut. Lily Publisher. Yogyakarta. 122 hal.

Laily. 2010. Olahan Dari Kentang. Kanisius. Yogyakarta

Lestiani, L. 2008. Bahan Makanan Sumber Protein dan Sifat-sifatnya. Jakarta: UI press.

McGee, H. 2004. On Food and Cooking. Scribner. United States Of America

Moeljanto. 1992. Pengawetan dan Pengolahan Hasil Perikanan. Penebar Swadaya. Jakarta

Muchtadi, D. 1989.Evaluasi Nilai Gizi Pangan. Bogor : Pusat Antar Universitas Pangan dan Gizi, Institut Pertanian Bogor.

Muhammad Zaid A. 2015. Profil Asam Amino Ikan Jelawat (Leptobarbus hoevenii) Berdasarkan Perbedaan Umur Panen. Universitas Riau. Pekanbaru 
Nakai, S., Modler, H.W. 2000. Food Protein, Processing Application. USA :Wiley-VHC inc

Napsarina, IH. 2016. Studi Formulasi Sosis Ikan Jelawat (Leptobarbus hoevani) dengan Penggunaan Jumlah Tepung Tapioka Berbeda Terhadap Penerimaan Konsumen. Universitas Riau. Pekanbaru

Nuraini. 2010. Pemanfaatan Produk Kaya Fermentasi Kaya Karoten sebagai Jagung dalam Ramsum Ayam. UNAD

Okada, M. 1990. Fish as raw materi fishery products. Didalam Science of Processing Marine Food Product. Motohiro T, Hashimoto K, Kayama $M$ and Takunaga $T$ (Editor). Japan:International Agency

Prasetyo, M. N, Nirmala. S, dan Sri B. 2012. Pembuatan Kecap dari Ikan Gabus Secara Hidrolisis Enzimatis Menggunakan Sari Nanas. Jurnal Teknologi Kimia dan Industri. Vol 1, No. 1

Priebe K. 2007. Parasiten de Fischfilets. Berlin:Springer

Purwaningsih S, et.al. 2014. Komposisi Kimia dan Asam Lemak Ikan Gelodok Akibat Pengolahan Suhu Tinggi. Institute Pertanian Bogor. Bogor

Rahardjo, MF., Djaja SS, Ridwan A, Sulistiono. 2011. Iktiology. Bandung (ID):Lubuk Agung

Rosa, R. Bandarra NM, dan Nunes ML. 2007. Nutrisional Quality Of African Catfish (Clarias gariepinus) : A Positive Criterion For the Future development of the European production of Siluroidei International Journal of Food
Science and Technology 42:342351

Sartika, R. 2009. Pengaruh Suhu dan Lama Proses Pengukusan Terhadap Pembentukan Asam Lemak Trans. Makaira Sains

Satora, L., Kuciel M, Gawlikowski T. 2008. Catfish Stings and The Venom Apparatus of The African Catfish Clarias gariepinus (Burchell 1822) and Stinging Catfish Heteropneustes fossilis (Bloch 1794). Ann Agric Environ Med Vol. 15: 127-167

Selcuk, A., Ozden O, Erkan N. 2010.Effect of frying, grilling, and steaming on amino acid composition of marine fishes. Journal of Medicinal Food 13(6): 1524-1531

Sukarsa, R. D. 2004. A Study Of Activity Of Omega-3 Fatty Acid Of Some Marine Fish In Mice As The Experimental Animals. Buletin teknologi Hasil Perikanan. Vol: VII

Sumiati, T. 2008. Pengaruh Pengolahan terhadap mutu Cerna Protein Ikan Mujair (Tilapia mossambica). [Skripsi]. Institut Pertanian Bogor

Susyiana, EL. 2008. Nori Imitasi Berbahan Dasar Edible Film Surimi Ikan Nila (Oreochromis niloticus). [Skripsi]. Institut Pertanian Bogor. Bogor

Suzuki, T. 1981. Fish and Krill Protein Processing Technology. London: Applied Science Publisher LTD

Villanueva R, Bustamante P. 2006. Compositionin essential and nonessential elements ofearly stages of chepalopods and dietary effects on the elemental profiles of Octopus Vulgaris paralarvae. Aquaculture 
261:225-240.Teknologi Hasil

Perikanan:Institut Pertanian

Bogor.

Weber J, Viviane CB, Christiane PR, Andre MV, Tatiana E. 2008. Effect different cooking methods on the oxidation, proximate, and fatty acid composition of silver catfish (Rhamdia quelen) fillets. Food Chemistery 106: 140-146. Doi: 10.1016/j.foodchem.2007.05.052

Winarno, F.G. 2008. Kimia Pangan dan Gizi Edisi Terbaru. Penerbit MBRIO PRESS. Bogor

Winarno. 2002.Enzim Pangan. Penerbit PT.Gramedia. Jakarta

Zaelanie, K., Kartikaningsih H. 2008. Pengaruh pengukusan dan penggorengan kadar formalin ikan laying (Decapterus spp.) berformalin. Jurnal Penelitian Perikanan 11(1): 37-41

[AOAC] Association of Official Analytical Chemist. 2005. Official Method of Analysis of The Association of Official Analytical of Chemist. Arlington: The Association of Official Analytical Chemist, Inc

\section{E-mail :}

srokayah14@yahoo.com sumarto1976@yahoo.co.id edisonsona@yahoo.co.id 